\title{
Edukasi Home Pharmacy Care terhadap Kepatuhan dan Kontrol Glukosa Darah pada Pasien Diabetes Melitus
}

(The effect of home pharmacy care education on adherence and blood glucose control in patients with diabetes mellitus)

\author{
Siwi Padmasari*, Fajriyati Nur Azizah \& Niken Larasati \\ Fakultas Kesehatan Universitas Jenderal Achmad Yani Yogyakarta, Jl. Ringroad Barat, Gamping Kidul, Ambarketawang, \\ Kec. Gamping, Kabupaten Sleman, Daerah Istimewa Yogyakarta
}

\begin{abstract}
Diabetes Mellitus (DM) is a chronic disease due to an increase in blood glucose levels. Adherence with taking medication is an important factor in controlling blood glucose levels. One of the interventions that can be carried out by pharmacists comprehensively for chronic diseases is pharmacist education through Home Pharmacy Care (HPC). The purpose of this study was to determine the effect of pharmacist education through HPC in type 2 DM patients in improving fasting blood glucose (FBG) monitoring and control. This study used a quasi-experimental pretest-posttest design with a control group design conducted in August-November 2020. The sample in this study was type 2 DM patients who participated in the Prolanis program at Mlati II Public Health Center Sleman, Yogyakarta. The total sample in this study was 60 patients from 65 patients divided into control and intervention group who were selected by simple random sampling method. Level of adherence was carried out using the ProMAS questionnaire and glucose test instruments to measure FBG levels. Data analysis used the Chi-square test to assess the differences between the patients, the Wilcoxon test to compare the pretest and posttest data in each group, and the Mann Whitney test to compare the level and achievement of FBG in the two groups. The results showed that education through HPC could improve adherence with $p=0.002(p<0.05)$ and FBG control with an average reduction in FBG levels in the intervention group was $53.67 \pm 24.31 \mathrm{mg} / \mathrm{dL}$ and $p=0.021$ ( $p<0.05$ ). This study concludes that education through HPC can improve adherence and attainment of fasting blood glucose levels.
\end{abstract}

Keywords: home pharmacy care; diabetes melitus; adherence; and fasting blood glucose level.

ABSTRAK: Penyakit Diabetes Melitus (DM) termasuk penyakit yang bersifat kronis akibat terjadinya peningkatan kadar glukosa darah. Kepatuhan minum obat merupakan faktor penting dalam mengontrol kadar glukosa darah. Salah satu intevensi yang dapat dilakukan oleh apoteker secara komprehensif untuk pasien dengan penyakit kronis adalah edukasi apoteker melalui home pharmacy care (HPC). Tujuan penelitian ini adalah untuk mengetahui pengaruh edukasi apoteker melalui HPC pada pasien DM dalam meningkatkan kepatuhan dan kontrol glukosa darah puasa (GDP). Penelitian ini menggunakan rancangan quasiexperimental pretest-posttest with control group design yang dilakukan pada bulan Agustus-November 2020. Subyek uji dalam penelitian ini adalah pasien DM tipe 2 yang mengikuti program Prolanis di Puskesmas Mlati II Sleman, Yogyakarta. Total subyek uji dalam penelitian ini sebanyak 60 pasien dari 65 pasien yang terbagi menjadi kelompok kontrol (30 pasien) dan intervensi (30 pasien) yang dipilih dengan metode simple random sampling. Pengukuran tingkat kepatuhan dilakukan dengan menggunakan instrumen kuesioner ProMAS dan glucose test untuk mengukur kadar GDP. Data dianalisis menggunakan uji Chi square untuk meniliai perbedaan karakteristik pasien, uji Wilcoxon untuk membandingkan data pretest dan posttest pada masing-masing kelompok dan uji Mann Whitney untuk membandingkan tingkat kepatuhan dan ketercapaian GDP pada kedua kelompok. Hasil penelitian menunjukkan bahwa edukasi melalui HPC dapat meningkatkan kepatuhan $p=0,002(p<0,05)$ dan kontrol GDP dengan rata-rata penurunan kadar GDP kelompok intervensi adalah 53,67 $\pm 24,31 \mathrm{mg} / \mathrm{dL}$ dan $p=0,021(p<0,05)$. Kesimpulan dari penelitian ini adalah pemberian edukasi melalui HPC dapat meningkatkan kepatuhan dan ketercapaian kadar glukosa darah puasa.

Kata kunci: home pharmacy care; diabetes mellitus; kepatuhan; glukosa darah puasa.

\section{Pendahuluan}

World Health Organization (WHO) menyatakan bahwa Diabetes Melitus (DM) sebagai salah satu keadaan darurat kesehatan global. Menurut data Riset Kesehatan Dasar (Riskedas) 2018 menunjukkan peningkatan prevalensi $5 \%$ dari total jumlah penduduk Indonesia. Menurut

\section{International Diabetes Federation}

(IDF), 1 diantara 16 orang yang berumur 20-79 tahun di Indonesia adalah penderita penyakit kronis terutama DM tipe 2. Jumlah tersebut diperkirakan meningkat sebesar 31\% dalam kurun waktu

*Corresponding Author: Siwi Padmasari Fakultas Kesehatan Universitas Jenderal Achmad Yani Yogyakarta, Jl. Ringroad Barat, Gamping Kidul, Ambarketawang, Kabupaten Sleman, Daerah Istimewa Yogyakarta, 55294 | Email: siwipadmasari29@gmail.com

\section{Article history}

Received: 02 Apr 2021 Accepted: 15 Jun 2021 Published: 05 Agust 2021

Access this article

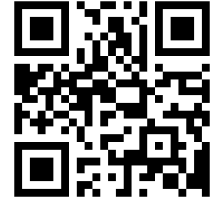


15 tahun [1]. Tingginya prevalensi DM yang terus meningkat setiap tahunnya, menuntut tenaga kesehatan untuk melakukan evaluasi dalam pelayanan kesehatan terutama dalam terapi farmakologi menggunakan obat antidiabetik [2].

Kepatuhan terhadap pengobatan antidiabetik adalah faktor utama untuk mencapai keberhasilan terapi pada pasien DM tipe 2. Beberapa faktor yang dapat mempengaruhi kepatuhan penggunaan obat antidiabetik meliputi pemahaman pasien akan regimen pengobatan, manfaat pengobatan, efek samping yang potensial, biaya dan kompleksitas dari terapi [3]. Kepatuhan merupakan faktor penting dalam mengontrol kadar glukosa darah. Kepatuhan yang tinggi terhadap pengobatan dapat mencegah terjadinya komplikasi makrovaskular dan mikrovaskular. Keadaan hiperglikemi yang tidak terkontrol pada pasien dengan diabetes melitus akan mempercepat penurunan fungsi kognitif dan menyebabkan perubahan aliran darah ke otak. Perubahan aliran darah tersebut dapat menyebabkan penurunan daya ingat pada pasien DM yang berdampak pada kepatuhan minum obat [4].

Diperlukan suatu upaya untuk memastikan kepatuhan minum obat dari obat yang telah diresepkan sehingga pasien mendapatkan manfaat pengobatan yang maksimal [5]. Intervensi yang dapat dilakukan salah satunya dengan pelaksanaan edukasi melalui HPC. Penerapan program HPC bagi apoteker bertujuan untuk mendampingi pasien dalam menjalani pengobatan, melakukan kajian terkait pengobatan pasien, memberikan edukasi terkait penyakit dan cara penggunaan obat serta monitoring keberhasilan terapi pasien [2]. Program HPC sangat bermanfaat dalam meningkatkan pemahaman dalam pengelolaan dan penggunaan obat terutama yang digunakan dalam jangka panjang. Edukasi apoteker melalui HPC merupakan sistem pelayanan kefarmasian yang belum banyak diterapkan dalam pelayanan kesehatan [6]. Berdasarkan uraian tersebut, penelitian ini bertujuan untuk mengetahui pengaruh edukasi melalui HPC pada pasien DM tipe 2 terhadap kepatuhan dan kontrol kadar glukosa darah puasa.

\section{Metode Penelitian}

\section{Subyek Penelitian}

Sampel dihitung menggunakan rumus besar sampel uji hipotesis numerik berpasangan. Jumlah sampel inklusi pada penelitian ini sebanyak 60 pasien dari total 65 pasien yang terbagi merata kedalam kelompok kontrol dan intervensi. Pengambilan sampel menggunakan total sampling dan penentuan kelompok pretest-posttest subjek penelitian dilakukan dengan simple random sampling dimana setiap pasien yang memenuhi kriteria inklusi penelitian memiliki probabilitas yang sama untuk dimasukkan dalam kelompok kontrol dan intervensi. Pasien DM tipe 2 yang sesuai dengan kriteria inklusi secara acak akan dikelompokkan menjadi kelompok kontrol dan intervensi. Kelompok kontrol merupakan kelompok pasien DM tipe 2 yang tidak mendapatkan layanan edukasi apoteker melalui HPC sedangkan kelompok intervensi adalah kelompok pasien DM tipe 2 yang mendapatkan edukasi apoteker melalui HPC. Kriteria inklusi pada penelitian ini adalah pasien dengan usia $>18-90$ tahun, terdiagnosis DM tipe 2 dengan atau tanpa penyakit penyerta minimal 3 bulan sebelum penelitian berlangsung, mendapatkan obat antidiabetik oral dengan atau tanpa insulin, belum pernah mendapatkan layanan HPC secara sistematis. Sedangkan kriteria eksklusi adalah pasien dengan jadwal kontrol tidak rutin dan pasien mengundurkan diri selama penelitian berlangsung.

\section{Pelaksanaan HPC}

Pelaksanaan edukasi apoteker melalui HPC dilaksanakan di puskesmas dan di rumah pasien selama 2 bulan dengan kunjungan sebanyak 2 kali dengan durasi kunjungan selama 30 menit. Pemilihan pasien dilakukan di ruang pelayanan farmasi di puskesmas yang sesuai dengan kriteria inklusi dalam penelitian ini. Pasien yang bersedia mengikuti penelitian kemudian mengisi lembar informed consent. Pada bulan pertama seluruh pasien dalam kelompok kontrol dan intervensi diberikan kuesioner kepatuhan ProMAS dan dilakukan pengukuran kadar GDP di laboratorium puskesmas untuk mendapatkan data pretest. Setelah data pretest di dapatkan, pasien yang berada dalam kelompok intervensi diberikan layanan edukasi melalui HPC selama 1 bulan. Edukasi HPC dilaksanakan selama 1 bulan dengan kunjungan secara langsung sebanyak 2 kali yaitu pada minggu 1 dan 4 ditambah dengan komunikasi melalui media virtual maupun telfon seluler yang dilakukan minimal 2 kali dalam 1 minggu. Kunjungan secara langsung kepada pasien di masa pandemi dilakukan oleh apoteker dengan menerapkan protokol kesehatan dengan menggunakan alat pelindung diri serta menjaga jarak. Seluruh pelaksanaan HPC menggunakan pedoman pelayanan kefarmasian di rumah [7]. Tahapan pelaksanaan HPC yaitu

a) Kunjungan pertama dilakukan pada awal bulan dengan kegiatan diskusi ringan dengan pasien dan atau keluarga pasien untuk membangun kepercayaan, membahas tentang manfaat, keuntungan, dan kerugian program HPC serta 
diskusi mengenai permasalahan pengobatan yang dirasakan pasien. Permasalahan terkait pengobatan yang dibicarakan pada HPC adalah tentang penggunaan obat antidiabetik, kepatuhan penggunaan obat, dan kendala yang dihadapi pasien untuk kemudian dilakukan identifikasi dan evaluasi. Pasien juga diberikan edukasi penggunaan obat antidiabetik yang tepat sehingga target glukosa darah dapat tercapai.

b) Kunjungan kedua dilakukan pada akhir bulan untuk menyampaikan rencana yang telah disusun berdasarkan kendala yang disampaikan oleh pasien pada kunjungan pertama. Selain itu juga dilakukan kembali identifikasi masalah baru yang mungkin dapat muncul.

\section{Alat Ukur}

Instrumen penelitian menggunakan kuesioner Probabilistic Medication Adherence Scale (ProMAS). Kuesioner ini terdiri dari 18 butir pertanyaan dengan jawaban "ya" akan bernilai 0 dan jawaban "tidak" bernilai 1 serta pernyataan dengan tanda (R), bernilai 1 untuk jawaban "ya" dan bernilai 0 untuk jawaban "tidak". Tingkat kepatuhan pasien dinilai dengan melihat jumlah skor jawaban, yaitu dikatakan rendah (skor 0-4), rendah sedang (skor 5-9), sedang tinggi (skor 10-15) dan tinggi (skor 1618) [8]. Penilaian kontrol glukosa darah dinilai berdasarkan pemeriksaan GDP setiap bulannya. Pengisian kuesioner dilakukan langsung oleh pasien. Apabila pasien tidak bersedia mengisi sendiri maka kuesioner dibacakan oleh peneliti dan pasien mengisi sendiri sesuai jawaban pada lembar kuesioner.

\section{Analisis Statistik}

Subjek penelitian yang telah terpilih kemudian dibagi menjadi kelompok kontrol dan intervensi masing-masing 30 responden. Kedua kelompok diukur tingkat kepatuhan dan kadar GDP sebagai data pretest pada bulan pertama. Kelompok kontrol tidak diberikan layanan edukasi apapun sedangkan kelompok intervensi diberikan layanan edukasi apoteker melalui HPC. Pada bulan kedua pasien datang untuk kontrol rutin, kemudian diukur kembali tingkat kepatuhan dan kadar glukosa darah sebagai data posttest. Data karakteristik pasien disajikan secara deskriptif. Data dianalisis menggunakan uji Chi square untuk meniliai perbedaan karakteristik pasien, uji Wilcoxon untuk membandingkan data pretest dan posttest pada kelompok kontrol dan intervensi dan uji Mann Whitney untuk membandingkan tingkat kepatuhan dan ketercapaian GDP pada kedua kelompok

\section{Hasil dan Diskusi}

\section{Karakteristik Pasien}

Sebaran data karakteristik responden dapat terlihat pada Tabel 1. Karakteristik responden yang mendominasi pada penelitian ini berjenis kelamin perempuan dengan rentang usia 61-75 tahun yang memiliki status pendidikan setara Sekolah Menengah Atas (SMA). Mayoritas pasien DM pada kelompok kontrol mengidap DM selama 1-5 tahun dan kelompok intervensi selama lebih dari 15 tahun. Pasien DM dalam penelitian ini mayoritas memiliki penyakit penyerta yaitu hipertensi. Mayoritas responden DM mendapatkan regimen antidiabetik secara kombinasi antidiabetik oral yang memiliki mekanisme kerja berbeda maupun kombinasi dengan antidiabetik non-oral seperti insulin. Antidiabetik oral yang banyak dikombinasikan adalah metformin dan glimepirid. Jumlah obat yang diresepkan juga bervariasi mengikuti ada tidaknya penyakit penyerta dan keparahan penyakit. Mayoritas responden menerima obat sebanyak 1-3 macam obat dengan mekanisme kerja yang berbeda untuk mengatasi DM dan penyakit penyerta lainnya.

Prevalensi kejadian DM tipe 2 pada perempuan lebih tinggi daripada laki-laki. Perempuan lebih mudah mengidap DM karena secara fisik perempuan memiliki peluang peningkatan Indeks Masa Tubuh (IMT) yang lebih besar [9]. Sindroma siklus bulanan (premenstrual syndrome), pasca-menopose yang membuat distribusi lemak tubuh mudah terakumulasi sehingga meningkatkan risiko terkena DM tipe 2 [10]. Hormon estrogen pada perempuan juga tidak mampu menghasilkan High Density Lipoprotein (HDL), sehingga meningkatkan aterosklerosis yang menyebabkan peningkatan tekanan darah pada wanita [11]. Pasien DM dengan usia $>50$ tahun dapat meningkatkan kejadian DM tipe 2 karena penuaan menyebabkan menurunnya sensitivitas insulin dan menurunnya fungsi tubuh untuk proses metabolisme glukosa [12]. Menurut hasil riset kesehatan (2013) prevalensi DM tipe 2 berdasarkan diagnosis dokter dan gejala meningkat sesuai dengan bertambahnya usia, namun mulai usia $>65$ tahun prevalensi DM cenderung menurun [13].

Pasien dengan tingkat pendidikan yang tinggi memiliki tingkat pengetahuan, perhatian, dan kepatuhan yang lebih baik dalam menjalankan terapi. Tingkat pendidikan memiliki pengaruh terhadap kejadian DM tipe 2. Individu yang tingkat pendidikan lebih tinggi memiliki banyak pengetahuan tentang kesehatan sehingga akan meningkatkan kesadaran dalam menjaga kesehatannya [10]. Lama menderita DM $>7$ tahun merupakan faktor 
Tabel 1. Karakteristik pasien diabetes melitus tipe II

\begin{tabular}{|c|c|c|c|c|c|}
\hline \multirow{2}{*}{ Karakteristik } & \multicolumn{2}{|c|}{ Kelompok Kontrol } & \multicolumn{2}{|c|}{ Kelompok Intervensi } & \multirow{2}{*}{$p$ value } \\
\hline & $n$ & $\%$ & $\mathrm{n}$ & $\%$ & \\
\hline \multicolumn{6}{|l|}{ Jenis Kelamin } \\
\hline Laki-laki & 13 & 43,3 & 6 & 20 & 0,418 \\
\hline Perempuan & 17 & 56,7 & 24 & 80 & \\
\hline \multicolumn{6}{|l|}{ Usia (tahun) } \\
\hline $18-45$ & 1 & 3,3 & 1 & 3,3 & 0,705 \\
\hline $46-60$ & 8 & 26,7 & 12 & 40 & \\
\hline $61-75$ & 18 & 60 & 14 & 46,7 & \\
\hline $76-90$ & 3 & 10 & 3 & 10 & \\
\hline \multicolumn{6}{|l|}{ Pendidikan terakhir } \\
\hline SD & 1 & 3,3 & 2 & 6,7 & 0,779 \\
\hline SMP & 6 & 20 & 1 & 3,3 & \\
\hline SMA & 18 & 60 & 23 & 76,7 & \\
\hline Diploma/Sarjana & 5 & 16,7 & 4 & 13,3 & \\
\hline \multicolumn{6}{|l|}{ Penyakit Penyerta } \\
\hline Tanpa Penyerta & 3 & 10 & 8 & 26,7 & 0,561 \\
\hline Dengan Penyerta & 27 & 90 & 22 & 73,3 & \\
\hline \multicolumn{6}{|c|}{ Lama Menderita DM (tahun) } \\
\hline $1-5$ & 3 & 10 & 17 & 56,7 & 0,516 \\
\hline $6-15$ & 13 & 43,3 & 10 & 33,3 & \\
\hline $16-30$ & 14 & 46,7 & 3 & 10 & \\
\hline \multicolumn{6}{|c|}{ Regimen Obat Antidiabetik } \\
\hline Tunggal & 10 & 33,3 & 14 & 46,7 & 0,198 \\
\hline Kombinasi & 20 & 66,7 & 16 & 53,3 & \\
\hline \multicolumn{6}{|c|}{ Jumlah Obat yang diresepkan } \\
\hline 1-3 obat & 22 & 73,3 & 18 & 60 & 0,508 \\
\hline $4-6$ obat & 8 & 26,7 & 12 & 40 & \\
\hline
\end{tabular}

Keterangan: $p$ value menggunakan Uji Chi-square

risiko tinggi terjadinya komplikasi, hal ini disebabkan karena semakin lama individu menderita DM maka kadar glukosa darah semakin tidak terkontrol sehingga menimbulkan hiperglikemi berkepanjangan [14]. Lama penyakit mempunyai korelasi yang positif dengan kepatuhan, semakin lama penyakit maka semakin tinggi tingkat kepatuhan [6].

Beberapa penelitian menyebutkan bahwa kombinasi antidiabetik banyak digunakan pada pengobatan DM tipe 2. Pemberian antidiabetik disesuaikan dengan kondisi dan kebutuhan pasien sesuai algoritma terapi DM tipe 2, mulai dari monoterapi kemudian dilanjutkan dengan kombinasi antidiabetik [15]. Jumlah obat yang diresepkan tergantung pada kondisi klinis pasien. Semakin banyak penyakit penyerta yang dimiliki pasien, maka jumlah obat yang diresepkan juga semakin meningkat [16].

\section{Pengaruh HPC terhadap Kepatuhan Pengobatan}

Pada awal program HPC masalah penggunaan obat yang diperoleh adalah tentang ketidakpatuhan pasien. Secara umum permasalahan ketidakpatuhan pasien disebabkan oleh faktor lupa, bosan, rasa tidak nyaman karena timbul efek samping obat dan merasa gejala sudah membaik sehingga tidak meneruskan 
pengobatan. Berdasarkan hasil wawancara didapatkan bahwa terdapat pasien yang mengambil tindakan sendiri dengan menurunkan dosis tanpa memberitahukan petugas kesehatan di puskesmas karena takut dengan pengobatan jangka panjang yang harus dilakukan. Bentuk intervensi apoteker yang dapat dilakukan untuk tipe pasien seperti ini adalah dengan memberikan edukasi dan konseling agar pasien memahami bahwa pengobatan yang dilakukan oleh dokter sudah melalui pertimbangan tertentu sesuai dengan kondisi pasien. Pada pasien yang tidak patuh karena faktor lupa minum obat, bentuk intervensi yang dapat diberikan yaitu dengan meminta pasien untuk meletakkan obat di tempat yang paling mudah dijangkau dan terlihat. Selain itu memberikan edukasi kepada keluarga pasien penting untuk dilakukan agar mendukung pasien untuk minum obat secara teratur.

Sebaran data distribusi tingkat kepatuhan yang diukur menggunakan kuesioner ProMAS dapat terlihat pada Tabel 2. Kuesioner ProMAS membagi tingkat kepatuhan menjadi 4 kelompok berdasarkan nilai skor yang didapatkan dari 18 butir pertanyaan [8]. Pada penelitian ini tingkat kepatuhan pasien untuk kelompok kontrol mayoritas berada pada tingkat rendah sedangkan untuk kelompok intervensi mayoritas responden memiliki tingkat kepatuhan rendah sedang. Dari 18 pertanyaan yang ada pada kuesioner ProMAS banyak responden yang menyatakan sering menghentikan pengobatan sendiri tanpa memberitahu dokter maupun tenaga kesehatan karena merasa keadaan tubuh sudah membaik. Responden juga menyatakan bahwa sering lupa untuk minum obat terutama saat beraktivitas di luar rumah.

Pengaruh edukasi apoteker melalui HPC terhadap kepatuhan pengobatan baik pada kelompok kontrol dan intervensi dianalisis secara statistik dengan uji Wilcoxon untuk menilai signifikansi hubungan data pretest dan posttest di setiap kelompok kontrol dan intervensi. Tabel
3 menunjukkan bahwa pada kelompok kontrol antara pretest dan posttest tingkat kepatuhan mengalami perubahan dengan $\Delta$ peningkatan sebesar 3,27 $\pm 2,76 \quad(\mathrm{p}=0,322)$ sedangkan pada kelompok intervensi, sesudah perlakuan edukasi HPC terjadi peningkatan kepatuhan dengan $\Delta$ peningkatan sebesar 4,73 $\pm 2,43 \quad(\mathrm{p}=0,002)$. Hasil ini menunjukkan bahwa terdapat perbedaan yang signifikan antara hasil pretest dan posttest pada kelompok intervensi tetapi tidak signifikan pada kelompok kontrol. Analisis statistik dilanjutkan dengan uji Mann Whitney untuk menilai signifikansi pengaruh HPC terhadap kepatuhan pada kelompok kontrol dan intervensi secara bersamaan. Pada tabel 3 dapat dilihat bahwa terdapat hubungan yang signifikan antara edukasi HPC dengan kepatuhan antara kelompok kontrol dan intervensi $(\mathrm{p}=0,002)$.

Pada sesi pretest rata-rata menyatakan bahwa responden lupa meminum semua tablet baik sadar maupun tidak sadar tetapi tidak pernah melewatkan lebih dari satu dosis per waktu minum. Alasan ketidakpatuhan responden mayoritas karena merasa kondisi tubuh sudah membaik, obat tidak dibawa saat beraktivitas di luar rumah, dan pasien takut jika mengkonsumsi obat jangka panjang akan menyebabkan kerusakan pada ginjal. Setelah dilakukan HPC pada kelompok intervensi terjadi peningkatan kepatuhan minum obat. Hal ini menujukkan bahwa intervensi apoteker dapat memberikan dampak yang signifikan $(p<0,05)$ dalam merubah kepatuhan minum obat.

Kepatuhan minum obat antidiabetik mempengaruhi kadar glukosa darah pasien, oleh sebab itu kepatuhan minum obat antidiabetik menjadi pilihan dalam mengendalikan kadar glukosa darah [17]. Penelitian lain menyebutkan bahwa pada pasien DM yang mendapatkan pelayanan kefarmasian dapat meningkatkan kepatuhan minum obat pasien sehingga dapat menunjang keberhasilan terapi dan mengendalikan kadar glukosa darah [18]. Hasil penelitian

Tabel 2. Distribusi kepatuhan minum obat pasien diabetes melitus kelompok kontrol dan intervensi

\begin{tabular}{|c|c|c|c|c|c|c|}
\hline \multirow[b]{2}{*}{ Tingkat Kepatuhan } & \multicolumn{2}{|c|}{ Kontrol } & \multirow[b]{2}{*}{$p$ value } & \multicolumn{2}{|c|}{ Intervensi } & \multirow[b]{2}{*}{$p$ value } \\
\hline & $\begin{array}{c}\text { Pretest } \\
\text { n (\%) }\end{array}$ & $\begin{array}{c}\text { Posttest } \\
\text { n (\%) }\end{array}$ & & $\begin{array}{c}\text { Pretest } \\
\text { n (\%) }\end{array}$ & $\begin{array}{c}\text { Posttest } \\
\text { n (\%) }\end{array}$ & \\
\hline Rendah (skor 0-4) & $18(60)$ & $12(40)$ & $0,015^{*}$ & $16(53,3)$ & $4(13,3)$ & $0,023^{*}$ \\
\hline Rendah Sedang (skor 5-9) & $12(40)$ & $16(53,3)$ & & $14(46,7)$ & & \\
\hline Sedang Tinggi (skor 10-15) & & $2(6,7)$ & & & $8(26,7)$ & \\
\hline Tinggi (skor 16-18) & & & & & $3(10)$ & \\
\hline Total & $30(100)$ & $30(100)$ & & $30(100)$ & $30(100)$ & \\
\hline
\end{tabular}

Keterangan: * berbeda signifikan $(\mathrm{p}<0,05)$ dengan uji Wilcoxon 
Tabel 3. Analisis pengaruh HPC terhadap kepatuhan pada kelompok kontrol dan intervensi

\begin{tabular}{|c|c|c|c|c|c|c|c|}
\hline \multirow[b]{2}{*}{ Variabel } & \multicolumn{3}{|c|}{ Kelompok Kontrol } & \multicolumn{3}{|c|}{ Kelompok Intervensi } & \multirow{2}{*}{$\begin{array}{c}\text { p-value } \\
\text { Mann } \\
\text { Whitney }\end{array}$} \\
\hline & $\begin{array}{c}\text { Pretest } \\
\text { (rerata } \pm \text { SD) }\end{array}$ & $\begin{array}{c}\text { Posttest } \\
\text { (rerata } \pm \text { SD) }\end{array}$ & $\Delta \pm S D$ & $\begin{array}{c}\text { Pretest } \\
\text { (rerata } \pm \text { SD) }\end{array}$ & $\begin{array}{c}\text { Posttest } \\
\text { (rerata } \pm \text { SD) }\end{array}$ & $\Delta \pm \mathrm{SD}$ & \\
\hline Tingkat Kepatuhan & $4,37 \pm 2,01$ & $7,63 \pm 4,45$ & $-3,27 \pm 2,76$ & $4,57 \pm 1,92$ & $9,3 \pm 3,84$ & $-4,73 \pm 2,43$ & $0,002^{b}$ \\
\hline$p$-value Wilcoxon & & 0,322 & & & $0,020^{a}$ & & \\
\hline
\end{tabular}

Keterangan: $a=$ Uji Wilcoxon; signifikansi secara statistik $(\mathrm{p}<0,05)$

$\mathrm{b}=$ Uji Mann Whitney; signifikansi secara statistik $(\mathrm{p}<0,05)$

ini sejalan dengan penelitian yang telah dilakukan oleh Nur Rasdianah (2020), bahwa kepatuhan pasien meningkat setelah mendapatkan intervensi dari apoteker melalui kegiatan HPC. Intervensi melalui kunjungan rumah mampu meningkatkan kepatuhan penggunaan obat sehingga dapat menunjang keberhasilan terapi pasien [19].

Penelitian ini sesuai dengan penelitian yang dilakukan sebelumnya yang menyatakan bahwa intervensi apoteker dapat menyebabkan modifikasi dalam sikap pasien terhadap terapi dan meningkatkan kepatuhan pengobatan [20]. Konseling apoteker adalah salah satu faktor penting untuk meningkatkan kepatuhan minum obat sehingga luaran klinik berupa kadar glukosa darah terkontrol akan tercapai secara maksimal [21]. Penelitian lain menyatakan bahwa supervisi penggunaan obat oleh apoteker dalam bentuk pelayanan HPC dapat meningkatkan kepatuhan penggunaan obat. Pelayanan supervisi apoteker melalui HPC terbukti mampu mengungkap lebih banyak permasalahan penggunaan obat dan memberikan solusi sebagai upaya meningkatkan ketercapaian kadar glukosa darah [22].

\section{Pengaruh HPC terhadap Kontrol Glukosa Darah}

Pengaruh edukasi apoteker melalui HPC terhadap kontrol GDP baik pada kelompok kontrol dan intervensi dianalisis secara statistik dengan uji Wilcoxon untuk menilai signifikansi hubungan data pretest dan posttest di setiap kelompok kontrol dan intervensi. Tabel 4 menunjukkan pada kelompok kontrol hasil rata-rata pemeriksaan GDP pretest sebesar 228,7 mg/dL dan hasil rata-rata pemeriksaan GDP posttest sebesar 176,7 mg/dL. Pada kelompok kontrol tidak menunjukkan rata-rata penurunan GDP yang signifikan yaitu sebesar 52,07 $\mathrm{mg} / \mathrm{dL}(\mathrm{p}=0,816)$. Pada kelompok intervensi, sebelum dilakukan HPC diperoleh rata-rata pemeriksaan GDP yang tidak terkontrol, yaitu lebih dari $126 \mathrm{mg} / \mathrm{dL}$ (rata-rata GDP 165,8 mg/dL). Setelah dilakukan HPC terjadi perbaikan rata-rata GDP yaitu sebesar $112,17 \mathrm{mg} / \mathrm{dL}$ dengan penurunan rata-rata GDP yang signifikan yaitu sebesar 53,67 mg/dL ( $p=0,000)$. Hasil ini menunjukkan bahwa terdapat perbedaan yang signifikan antara hasil pretest dan posttest pada kelompok intervensi tetapi tidak signifikan pada kelompok kontrol. Analisis statistik dilanjutkan dengan uji Mann Whitney untuk menilai signifikansi pengaruh HPC terhadap kontrol GDP pada kelompok kontrol dan intervensi secara bersamaan. Pada tabel 4 dapat dilihat bahwa terdapat hubungan yang signifikan antara edukasi HPC dengan kontrol GDP antara kelompok kontrol dan intervensi $(p=0,021)$.

Hal ini menunjukkan bahwa dengan adanya HPC pada kelompok intervensi terjadi peningkatan kepatuhan pasien yang kemudian dapat meningkatkan ketercapaian target kadar GDP yaitu $<126 \mathrm{mg} / \mathrm{dL}$. Berbeda dengan kelompok kontrol yang tidak mendapatkan edukasi dengan HPC, akan menyebabkan pengetahuan pasien tentang penyakit dan pengobatan rendah, kemudian berdampak pada rendahnya kadar kepatuhan minum obat [23]. Kepatuhan yang rendah terhadap terapi antidiabetik akan menyebabkan kadar glukosa darah puasa setelah

Tabel 4. Analisis pengaruh HPC terhadap kontrol GDP pada kelompok kontrol dan intervensi

\begin{tabular}{|c|c|c|c|c|c|c|c|}
\hline \multirow[b]{2}{*}{ Variabel } & \multicolumn{3}{|c|}{ Kelompok Kontrol } & \multicolumn{3}{|c|}{ Kelompok Intervensi } & \multirow{2}{*}{$\begin{array}{c}\text { p-value } \\
\text { Mann } \\
\text { Whitney }\end{array}$} \\
\hline & $\begin{array}{c}\text { Pretest } \\
\text { (rerata } \pm \text { SD) }\end{array}$ & $\begin{array}{c}\text { Posttest (re- } \\
\text { rata } \pm \text { SD) }\end{array}$ & $\Delta \pm S D$ & $\begin{array}{c}\text { Pretest } \\
\text { (rerata } \pm \text { SD) }\end{array}$ & $\begin{array}{c}\text { Posttest (re- } \\
\text { rata } \pm \text { SD) }\end{array}$ & $\Delta \pm S D$ & \\
\hline Tingkat Kepatuhan & $228,77 \pm 18,23$ & $176,70 \pm 43,88$ & $52,07 \pm 36,50$ & $165,83 \pm 37,62$ & $112,17 \pm 21,26$ & $53,67 \pm 24,31$ & $0,021^{\mathrm{b}}$ \\
\hline p-value Wilcoxon & & 0,816 & & & $0,000^{a}$ & & \\
\hline
\end{tabular}

Keterangan: $a=$ Uji Wilcoxon; signifikansi secara statistik $(p<0,05)$

$\mathrm{b}=\mathrm{Uji}$ Mann Whitney; signifikansi secara statistik $(\mathrm{p}<0,05)$ 
Tabel 5. Distribusi penurunan kadar glukosa darah puasa (GDP) kelompok kontrol dan intervensi

\begin{tabular}{ccc}
\hline Penurunan Glukosa Darah Puasa & $\begin{array}{c}\text { Kontrol } \\
\mathbf{n}(\%)\end{array}$ & $\begin{array}{c}\text { Intervensi } \\
\mathbf{n}(\%)\end{array}$ \\
\hline$<40 \mathrm{mg} / \mathrm{dL}$ & $15(50)$ & $9(30)$ \\
$41-60 \mathrm{mg} / \mathrm{dL}$ & $5(16,67)$ & $9(30)$ \\
$>61 \mathrm{mg} / \mathrm{dL}$ & $10(33,33)$ & $12(40)$ \\
Total & $30(100)$ & $30(100)$ \\
\hline
\end{tabular}

pengukuran kedua tidak mencapai target yaitu $>126 \mathrm{mg} /$ dL. Intervensi HPC dapat meningkatkan pengetahuan pasien tentang penyakit dan pengobatan DM. Program edukasi apoteker yang menekankan kepatuhan terhadap regimen pengobatan secara keseluruhan, terutama untuk diet dan berolahraga serta tindak lanjut yang teratur memiliki manfaat yang lebih besar dalam kontrol glikemik dibandingkan hanya dengan menekankan kepatuhan pengobatan saja. Pendidikan terstruktur memiliki dampak positif pada kontrol glukosa dan hipoglikemia pada DM tipe 2 dan merupakan program wajib dalam perawatan rutin [13].

Luaran klinik yang digunakan dalam penelitian ini adalah kadar glukosa darah puasa. Pada tabel 5, terlihat pada kelompok kontrol mayoritas penurunan kadar glukosa darah puasa adalah $<40 \mathrm{mg} / \mathrm{dL}$ sedangkan pada kelompok intervensi adalah >61 mg/dL. Pada penelitian ini kepatuhan konsumsi obat antidiabetik pada obat metformin kombinasi dengan glimepirid dapat mengontrol glukosa darah pasien. Metformin merupakan obat antidiabetik pilihan utama bagi penderita yang gemuk, disertai dengan dislipidemia dan resistensi insulin [24]. Glimepirid merupakan obat golongan sulfonilurea yang berfungsi untuk meningkatkan sekresi insulin [25]. Terapi pengobatan yang baik dan benar akan sangat menguntungkan bagi pasien diabetes terutama bagi pasien yang menderita penyakit kronis [26].

Penelitian lain yang dilakukan sebelumnya menyebutkan bahwa terdapat pengaruh intervensi dan konseling apoteker terhadap tingkat pengetahuan, efikasi diri, kepatuhan, dan kontrol glukosa darah [6]. Kontrol glukosa darah dan pengetahuan dapat dijadikan parameter keefektifan program edukasi atau konseling. Penelitian Rokhman (2015) menyatakan bahwa pemberian layanan HPC dapat memperbaiki domain kontrol glukosa darah, kepatuhan dan kualitas hidup pasien diabetes melitus [27]. Dalam satu penelitian jangka pendek yang dilakukan oleh Hillen (2011) berupa program pemantauan intensif, pemberian edukasi, dan intervensi farmakologis menghasilkan peningkatan kontrol glikemik dalam 1,5 hingga 3 bulan. Edukasi yang diberikan secara individu pada pasien DM menghasilkan kontrol glukosa darah yang lebih baik [28]. Hasil penelitian ini sejalan dengan penelitian yang dilakukan oleh Nur Rasdianah (2020) yang menunjukkan bahwa pelayanan kefarmasian dapat meningkatkan kepatuhan penggunaan obat pasien sehingga dapat menunjang keberhasilan terapi. Kunjungan rumah juga dapat memperbaiki kontrol glikemik dan mengurangi risiko kardiovaskuler dan dapat meningkatkan kualitas hidup pasien [13]. Pemberian pelayanan kefarmasian berupa konseling dengan alat bantu (booklet dan penggunaan wadah khusus) lebih efektif menurunkan kadar glukosa darah dibandingkan konseling biasa [29].

\section{Kesimpulan}

Pemberian edukasi melalui Home Pharmacy Care dapat meningkatkan kepatuhan $(p=0,002)$ dan meningkatkan tercapainya target terapi/klinik yaitu kadar glukosa darah puasa (GDP), dengan rata-rata penurunan GDP kelompok

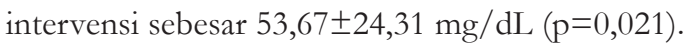

\section{Ucapan Terima Kasih}

Ucapan terimakasih penulis sampaikan kepada Direktorat Riset dan Pengabdian Masyarakat, Kementrian Riset dan Teknologi/ Badan Riset dan Inovasi Nasional atas dana hibah penelitian yang telah diberikan melalui program Penelitian Dosen Pemula (PDP) dengan Nomor Kontrak SPK/019/LPPM/UNJANI/VI/2020 tanggal 05 Juni 2020.

\section{Referensi}

[1]. Wibowo MIN, Setiawan D, Ikhwaniati ND, Sukma FA. Pengaruh Konseling dan Alat Bantu Pengingat Pengobatan terhadap Kepatuhan Minum Obat dan Outcome Klinik Pasien Diabetes Melitus dan Hipertensi. J IImu Kefarmasian Indones. 2020;18(2):169-76. 
[2]. Najiha MR, Utaminingrum W, Wibowo MIN. Peran Home Pharmacy Care pada Pasien Diabetes Melitus Tipe II Prolanis Terhadap Tingkat Kepatuhan dan Keberhasilan Terapi di BP Sentra Medika Lebaksiu Tegal. JTropPharmChem. 2017;4(2):60-5.

[3]. Trinovitasari N, Yasin NM, Wiedyaningsih C. Pengaruh Medication Therapy Management (MTM) terhadap Tingkat Pengetahuan dan Kualitas Hidup Pasien Diabetes Melitus Di Puskesmas Kota Yogyakarta. J Farm Indones. 2020;17(02):65-78.

[4]. Romadhon R, Saibi Y, Nasir NM. Kepatuhan Terhadap Pengobatan Pasien Diabetes Melitus Tipe 2 di Puskesmas Jakarta Timur. J Farm Galen. 2020;6(1):94-103. https://doi.org/10.22487/ j24428744.2020.v6.i1.15002

[5]. Fandinata SS, Darmawan R. Pengaruh Kepatuhan Minum Obat Oral Anti Diabetik Terhadap Kadar Gula Darah Pada Pasien Diabetes Mellitus Tipe II. J Bid IImu Kesehat. 2020;10(1):23-31.

[6]. Widyastuti S, Yasin NM, Kristina SA. Pengaruh Home Pharmacy Care Terhadap Pengetahuan, Kepatuhan, Outcome Klinik dan Kualitas Hidup Pasien Hipertensi. Maj Farm. 2019;15(2):105-12.

[7]. Kesehatan DJBK dan A. Pedoman Pelayanan Kefarmasian di Rumah (Home Pharmacy Care). Jakarta: Departemen Kesehatan Republik Indonesia; 2008.

[8]. Kleppe M, Lacroix J, Midden C. The Development of the ProMAS : a Probabilistic Medication Adherence Scale. Dove Med Press J. 2015;9:355-67.

[9]. Kurniawaty E, Yanita B. Faktor-Faktor yang Berhubungan dengan Kejadian Diabetes Melitus Tipe II. Majority. 2016;5(April):27-31.

[10]. Trisnawati SK, Setyorogo S. Faktor Risiko Kejadian Diabetes Melitus Tipe II Di Puskesmas Kecamatan Cengkareng Jakarta Barat Tahun 2012. J IIm Kesehat. 2013;5(1):6-11.

[11]. Fajar DR, Stevani H, Kamaruddin. Gambaran Pola Pengobatan Diabetes Melitus pada Pasien Geriatri di Instalasi Rawat Inap Rumah Sakit Tk. II Pelamonia Makassar. Media Farm. 2020;XVI(1):42-8.

[12]. Sinuraya RK, Oktrina A, Handayani NK, Destiani DP, Puspitasari IM. Pelayanan Farmasi Klinis Meningkatkan Kontrol Gula Darah Pasien Diabetes Melitus. J Farm Klin Indones. 2019;8(4):271-80. https:// doi.org/10.15416/ijcp.2019.8.4.271

[13]. Rasdianah N, Martodiharjo S, Andayani TM, Hakim L. Pengaruh Pelayanan Kefarmasian di Rumah pada Pasien Diabetes Melitus Tipe 2 di Puskesmas Wilayah Kota Yogyakarta. J Manaj DAN PELAYANAN Farm (Journal Manag Pharm Pract. 2020;10(2):126. https://doi. org/10.22146/impf.46240

[14]. Putu N, Suryaningsih A, Purwahita A, Ayu A, Saraswati S, Aini SN. Faktor - Faktor Kepatuhan Penggunaan Obat Antidiabetes pada Pasien Diabetes Mellitus Tipe 2 di Poli Rawat Jalan Rumah Sakit X di Kabupaten Badung. Bali Int Sci Forum. 2020;1(1):18-24.

[15]. Ratnasari PMD, Andayani TM, Endarti D. Analisis Outcome Klinis Berdasarkan Kualitas Hidup dan Biaya Medik Langsung Pasien Diabetes Melitus Tipe 2. J Sains Farm Klin. 2020;7(57):15-22. https:// doi.org/10.25077/isfk.7.1.15-22.2020

[16]. Sammulia SF, Elfasyari TY, Pratama MR. Hubungan Karakteristik Pasien Diabetes Melitus dan Tingkat Kepatuhan Minum Obat di Rumah Sakit X Kota Batam. J JUMANTIK. 2020;5(2):138-46.
[17]. Jasmine NS, Wahyuningsih S, Thadeus MS. Analisis Faktor Tingkat Kepatuhan Minum Obat Pasien Diabetes Melitus di Puskesmas Pancoran Mas Periode Maret - April 2019. J Manaj Kesehat Indones. 2020;8(April):61-6.

[18]. Nugraheni AY, Sari IP, Andayani TM. Pengaruh Konseling Apoteker dengan Alat Bantu pada Pasien Diabetes Melitus. J Manaj dan Pelayanan Farm. 2015;5:233-40.

[19]. Rasdianah N, Martodiharjo S, Andayani TM, Hakim L. Gambaran Kepatuhan Pengobatan Pasien Diabetes Melitus Tipe 2 di Puskesmas Daerah Istimewa Yogyakarta. J Farm Klin Indones. 2016;5(4):249-57. https://doi.org/10.15416/ijcp.2016.5.4.249

[20]. Wahyuni KI, Prayitno AA, Wibowo YI. Efektivitas Edukasi Pasien Diabetes Mellitus Tipe 2 Terhadap Pengetahuan dan Kontrol Glikemik Rawat Jalan di RS Anwar Medika. 2019;06(01):1-9.

[21]. Swandari MTK, Sari IP, Kusharwanti AW. KEPATUHAN DAN HASIL TERAPI PASIEN HIPERTENSI DI POLIKLINIK PENYAKIT DALAM RSUD CILACAP PERIODE DESEMBER 2013 - JANUARI 2014. J Manaj dan Pelayanan Farm. 2014;4(4):219-29.

[22]. Nurfauzi Y, Wahyono D, Rahmawati F, Yasin NM. Inovasi Home Care Apoteker melalui Supervisi Penggunaan Obat Geriatri untuk Meningkatkan Kepatuhan Terapi Penyakit Kronis. Indones J Clin Pharm. 2020;9(2):147. https://doi.org/10.15416/ijcp.2020.9.2.147

[23]. Keban SA, Ramdhani UAYU. Hubungan Rasionalitas Pengobatan dan Self-care dengan Pengendalian Glukosa Darah pada Pasien Rawat Jalan di Rumah Sakit Bina Husada Cibinong ( Correlation of Treatment Rationality and Self-care with Blood Glucose Control in Outpatients Treated at Bina Hus. J IImu Kefarmasian Indones. 2016;14(1):66-72.

[24]. Adikusuma W, Qiyaam N, Nurbaety B, Partini T, Putra ES. Perbandingan Pengaruh Edukasi Melalui Layanan Pesan Singkat dan Booklet Terhadap Kepatuhan Pasien Diabetes Melitus. J IIm Ibnu Sina. 2017;2(1):44-50.

[25]. Wells BG, Schwighammer TL, DiPiro J, DiPiro C V. Pharmacotherapy Handbook. 10th ed. Cenveo Publisher Services; 2017.

[26]. Nanda OD, Wiryanto RB, Triyono EA. Hubungan Kepatuhan Minum Obat Anti Diabetik dengan Regulasi Kadar Gula Darah pada Pasien Perempuan Diabetes Mellitus. Amerta Nutr. 2018;340-8. https:// doi.org/10.20473/amnt.v2.i4.2018.340-348

[27]. Rokhman MR, Darakay CN, Raditya R. Pengaruh Pemberian Home Care oleh Apoteker pada Pasien Diabetes Melitus. J Manaj dan Pelayanan Farm. 2015;5(3):225-32.

[28]. Sperl-Hillen JA, Beaton S, Fernandes O, Von Worley A, VazquezBenitez G, Parker E, et al. Comparative effectiveness of patient education methods for type 2 diabetes: A randomized controlled trial. Arch Intern Med. 2011;171(22):2001-10. https://doi. org/10.1001/archinternmed.2011.507

[29]. Andito T, Aditya M. Optimalisasi Pesan Dalam Buku Edukasi Pasien Diabetes Melitus Melalui Komunikasi Visual. DeKaVe. 2019;12(2):3541. https://doi.org/10.24821/dkv.v12i2.3522. 